\title{
Overconfidence Bias, Comparative Evidences between Vietnam and Selected ASEAN Countries
}

\author{
Dzung Tran Trung PHAN*, Van Hoang Thu LE ${ }^{* *}$, Thanh Thi Ha NGUYEN**** \\ Received: January 01, 2020 Revised: February 01, 2020 Accepted: February 06, 2020.
}

\begin{abstract}
The study aims to investigate the existence of overconfidence bias in Vietnam, Thailand, and Singapore. This paper focuses on the Vietnam Stock Market and other two countries of ASEAN, namely Singapore and Thailand. Data was collected over the period from January 1, 2014 to December 31, 2018, daily returns for each of the securities. This paper uses the time series method, namely ADF test, Granger Causality and VAR approach to find evidences of the overconfidence effect in Vietnam in relation to some ASEAN markets. The results show similarities between the observed countries with slight variations, with focus on Vietnam market. In general concrete evidences of overconfidence were found in both Vietnamese and Singaporean markets, in which Singaporean investors show higher degree of overconfidence than Vietnamese investors. Overconfidence is not as clear in Thai market, however a direct causal link from increased returns to increased investor confidence was found. From the model deployed in the paper, there are reasons to conclude that Thai investors are under-confident. The findings of the study shed lights into the existence of overconfidence bias in Vietnam, Thailand, and Singapore on a comparative basis, provide more insights and implications for future research in this new and rising field of research.
\end{abstract}

Keywords: Behavioral Finance, Overconfidence, Vietnam, ASEAN

JEL Classification Code: G10, G11, G41

\section{Introduction}

The assumption that all investors are rational is the basis for the conventional asset pricing models. However, more and more empirical evidences suggest that those models cannot explain many stylized facts observed in the real securities market. It results in growing interest in finding reasons why conventional asset-pricing model does not hold at all time. One potential idea that has grown into a whole branch of study called Behavioural Finance is that investors are not rational when making financial decisions,

${ }^{*}$ First Author and Corresponding Author. Vice Dean, Faculty of Banking and Finance, Foreign Trade University, Vietnam [Postal Address: 91 Chua Lang Street, Dong Da District, Ha Noi, 100000, Vietnam] Tel.: (+84) 0904216521, Email: fandzung@ftu.edu.vn

${ }^{* *}$ Research Scholar, Foreign Trade University, Vietnam. Email: lehoangthuvan@gmail.com

***Lecturer, Faculty of Banking and Finance, Foreign Trade University, Vietnam. Email: thanh.nth@ftu.edu.vn

() Copyright: The Author(s)

This is an Open Access article distributed under the terms of the Creative Commons Attribution NonCommercial License (https://creativecommons.org/licenses/by-nc/4.0/) which permits unrestricted noncommercial use, distribution, and reproduction in any medium, provided the original work is properly cited. which violates the most fundamental assumption of traditional finance theories. In this field of study, many cognitive as well as emotional biases affecting investors' way of thinking and feeling have been put forward as explanation for anomalies in individual investment decisions and the performance of financial markets. Overconfidence is one of the main biases in Behavioural Finance.

Featuring the nature of an immature market where there are numerous individual investors and speculation frequently happens, Vietnam stock market is subject to behavioural factors, especially investors' overconfidence. Therefore, the study of behavioural psychology proves to be necessary to the market and investors, particularly in the current period when Vietnam is now facing with various growth opportunities: The Comprehensive and Progressive Agreement for Trans-Pacific Partnership (CPTPP) entered into force, the Vietnam - EU Free Trade Agreement (EVFTA) has been finalized and will soon be signed, The US - China trade tension brings Vietnam advantages. These promising news can potentially trigger irrational beliefs of investors, drive investor sentiment and make them overconfident about the performance of Vietnam stock 
market. By realizing the existence of this bias, investors may return to their rational behaviour, which helps prevent consequences on the market level such as abnormal market returns and volatility. This is also the concern of the regulatory authorities if they want to ensure that Vietnam stock market functions efficiently. This would be an important task for the country as Vietnam has set target that the stock market could be upgraded to secondary emerging status in March 2020 by FTSE Russell after the revised securities law is approved in the eighth session of the National Assembly's 14th legislature. There were discussions of the importance of economic integration to development (Bong \& Premaratne, 2019; Hur \& Park, 2012; Tai \& Lee, 2009; Wong \& Chan, 2003)

The research is put in perspective and comparative basis with two ASEAN stock markets, which are Singapore and Thailand market. All three countries share similar characteristics in terms of economic, political and social conditions but growth paces of their economies and securities markets are varying. It can provide with meaningful comparisons among these three ASEAN markets and some lessons for improving the efficiency of Vietnam stock market. It is found by various studies, that economic integration and similar economic condition could generate a cross-affect situation between countries (Lee \& Zhao, 2014), with the short run causality from Japan and Korea to Chinese stock price, while Valadkhani and Chancharat (2008) found the dynamic link between Thai and international stock markets.

Overconfidence is a tendency in which investors overestimate their own knowledge, ability and the precision of information they own. Overconfidence may also refer to over-optimism about future events and the illusion of control. Overconfidence can be detected in many professional fields (clinical psychologists, physicians and nurses, lawyers, entrepreneurs...), especially stock investment. Choosing a stock that outperforms the market is a challenging task. Forecasting expected returns and risks of stocks can become unpredictable given any changes specific to firms or even the domestic and foreign business environment, which are very commonplace. Also, feedback can be noisy because the market is not highly efficient, which means that the market movements may not be meaningful. Instead, these movements are distorted by noises such as trending news, speculation or word-ofmouth rather than resulting from fundamental analysis of stocks. Thus, it might be difficult for investors to test their previous judgement about values of stocks or review their performance. These aforementioned features of equity investment can be attributed to why investing is greatly affected by overconfidence and why being aware of this psychological bias in investing is essential.

This paper focuses on the Vietnam Stock Market and other two countries of ASEAN, namely Singapore and Thailand due to two main reasons:

Firstly, these countries are now facing with the similar growth opportunities on the face of the trade war between the US and China, which can have major impacts on performance of these stock markets. The trend and the degree of impact on these three countries vary, which may reveal certain patterns in the impact of this event on the stock markets and investor sentiments.

In March 2018, US President Donald Trump has accused China of unfair trade in an attempt to spur more Chinese imports from the US and reduce its gaping trade deficit which stood at US\$419 billion in 2018. Since then, the US has imposed tariffs on each other's goods worth US $\$ 360$ billion. Despite negotiating effort of both parties, trade tensions between the US and China have been escalating. As an evidence, on 10/5/2019, the Office of the United States Trade Representative (USTR) published List 4 of the Section 301 regime of trade tariffs, which pledged to impose tariffs of up to 25 per cent on Chinese goods with a total annual trade value of US $\$ 300$ billion. In the meantime, trade tensions between the US and China are driving growth momentum for Southeast Asia's economies. American tariffs on Chinese-made goods result in a shift of manufacturing centres to ASEAN countries. In addition, the increase in foreign direct investment into ASEAN witnessed booming growth since 2017 and even rose faster since the trade war began.

However, Vietnam, Singapore and Thailand saw different impacts from this event. Vietnam could benefit the most, particularly in low-end manufacturing of technology products, textiles and other consumer goods, as electronics and related components amount to the biggest category of US imports from China. Besides, Vietnamese people are becoming more open to new products and opportunities (Phan, Nguyen, \& Bui, 2019). Thailand benefits from the US's tariffs on Chinese auto parts. Thailand's auto industry tends to win market share from Chinese competitors because its well-diversified trade links with the US, Japan and other parts of ASEAN can attract manufacturers that want to replace Chinese suppliers from their supply chain. On the contrary, Singapore may be prone to negative impact from the trade war. Because this country is heavily dependent on shipment to China and is part of the supply chain of ICT goods and many other products for China, which means that Singapore may be heavily exposed to impacts of tariffs on these products. By looking into these three stock markets, I may identify how the investor sentiment and possible overconfidence bias affect the stock markets given the impact of the trade war.

Secondly, there are varying results in the level of overconfidence biases in these three market taken from previous researches. Helen and Lib (2019) found a stronger 
overconfidence effect in the up-market for Singapore markets using the VAR model with up-market and downmarket sub-samples separately. On the other hand, Budsaratragoon, Lhaopadchan, Clacher, Hillier, and Hodgson (2012) carried experimental survey on Thailand members of Thai Government Pension Fund and argued that they are in lack of confidence due to general lack of financial knowledge. The contradictory results of overconfidence bias in these two markets will be tested and compared with Vietnamese investors.

\section{Literatures Review}

On the global scale, the first outstanding work about overconfidence is developed by Odean (1998) in which he found evidence of a positive causal relation running from stock returns to trading volume and attributed it to overconfidence. Many researches have contributed to the findings of overconfidence (Barber \& Odean, 2001; Biais, Hilton, Mazurier, \& Pouget, 2005; Glaser \& Weber, 2007). In short, the overconfidence hypothesis, among other things, offers the following hypotheses. First, overconfident investors have a tendency to overreact to private information and underreact to public information. Second, an increase in market gains (losses) leads to an increase (decrease) in investors' overconfidence, and consequently they trade more (less) aggressively in subsequent periods. Third, as overconfident investors, they fail to estimate risk appropriately, thus trade riskier securities. Fourth, excessive trading by overconfident investors in securities markets makes a contribution to the observed excessive volatility. The paper aims at testing the second hypothesis and is built with model following the approach (Gervais \& Odean, 2001; Odean, 1998)

Behavioural finance in general and overconfidence in particular are fields of study that are difficult for researchers to prove its existence and impacts on the performance of investors and the stock market as a whole. However, more and more scholars are paying attention to this subject. They contribute to an enormous and comprehensive collection of researches on different aspects of overconfidence using both empirical and experimental approach.

Overconfidence bias has been developed and expanded for years, but in Vietnam, there are limited works that study it in details. My, Toan, and Cuong (2016) is the only one that develops a model to test the existence of overconfidence in Vietnam stock market and to study its impact in depth. There are also papers discussing different aspects of behavioral biases in Vietnam using different approaches. Ton and Dao (2014) discussed overall psychological biases in Vietnam, Phan Tran Trung and Pham Quang (2019) explored the adaptive nature and found evidences supporting the evolution of Vietnamese financial market over time, Dang and Tran (2019) found experimental evidences of an abnormal existence of accrual in the Vietnam stock market, Ton and Dao (2014) explored demographical factors as predictors for investment decisions in Vietnam.

\subsection{Hypotheses}

\subsubsection{Testing the Existence of Overconfidence in Stock Market}

The existence of overconfidence on individual investor level is proved in a large questionnaire study (De Bondt, 1998). He found numerous signals of overconfidence in his sample: Investors are excessively optimistic about the performance of stocks they own but not about the market performance as a whole; in addition, they also set irrationally narrow confidence intervals for the variability of security prices.

Moreover, Trehan and Sinha (2011) also confirm the existence of overconfidence with similar prompts. In particular, investors take credit for their successes, strongly believe in their abilities to pick stock, make frequent transactions and are relatively optimistic about the Indian stock market, which are the most prominent factors leading to overconfidence. Chuang, Lee, and Wang (2013) investigated Asian investors' behavior following US market news and found evidences support the imitation, overconfidence became especially high in bullish times.

\subsubsection{Testing the Relationship between Overconfidence and Market Variables}

Overconfidence is considered as an explanation for trends in market variables including trading volume and volatility. Odean (1998), and Gervais and Odean (2001) have put forward the idea that overconfidence inflates expected trading volume, thus lowers the expected utility. Similar arguments that overconfidence leads to greater trading are presented (Benos, 1998; De Long, Shleifer, Summers, \& Waldmann, 1991; Hirshleifer \& Luo, 2001; Kyle \& Wang, 1997; Odean, 1998; Scheinkman \& Xiong, 2003).

Odean (1998) and Gervais and Odean (2001) also prove these hypotheses using a powerful quantitative method called Granger Causality test. They used two Granger causality tests. A bivariate Granger causality test is applied to find a positive causal relationship between stock returns and trading volumes. On the other hand, a trivariate Granger causality model use a variable besides stock return and trading volume to be a proxy for overconfidence, which is the consumer confidence index. The latter test aims to find a causal relationship between lagged stock return and trading volume due to overconfidence which is 
built up through past successes. The result is that stock returns positively Granger-cause both consumer confidence index and volume. It implies that increase in return makes investors more confident and raise their trading volume in subsequent periods. Another finding of them is that overconfidence does not drive stock returns despite positive relation between these two variables. It may suggest that investor sentiment cannot drive the market. Otherwise, according to (Benos, 1998), it may be due to the fact that overconfident investors make private information more publicly by rising volume, which quickly turn the market back to being efficient.

In terms of stock volatility, the prediction that volatility increases with overconfidence is drawn from the studies of (Gervais \& Odean, 2001; Odean, 1998; Scheinkman \& Xiong, 2003; Wang, 1998). Scheinkman and Xiong (2003) presents that overconfidence is a root of disagreement among investors. It is based on the rationale that due to overconfidence, investors believe their information is more accurate than it truly is. Those subjects would pay price that exceeds their evaluation of future dividends because they believe in the potential capital gains from it. This causes a significant bubble component in asset prices as even small differences of beliefs are sufficient to generate a trade. As a result, large trading volume together with high price volatility will drive the market to bubbles.

\subsection{Research Hypotheses}

Following previous findings as mentioned above, in this paper, there are three main hypotheses proposed as follows:

Hypothesis 1: Higher stock returns result in an increase in subsequent trading volume

Hypothesis 2: Higher stock returns result in an increase in subsequent confidence level of investors

Hypothesis 3: Investor overconfidence has an impact on market variables (returns and volume) either in a positive or negative way

The first two hypotheses should follow the exact trend, whereas the third hypothesis is not fixed in terms of the trend and is open for discussion whether overconfidence is a positive or negative bias in each stock market.

\section{Data and Methodology}

\subsection{Data Description}

\subsubsection{Aggregated Return and Trading Volume}

This paper's sample consists of three equity markets in the area of the South East Asia, which are: Vietnam,
Singapore and Thailand. Overconfidence hypotheses will be tested separately on each stock market, through which conclusions will be summarized for the purpose of comparison and implications.

For Vietnam stock market, the daily data from the VNIndex file are used to construct weekly observations. The weekly return of each stock is computed as the return from Wednesday's closing price to the follow Wednesday's one. If the following Wednesday's price is not available, Tuesday's or Thursday's one will be used. Weekly returns are determined by the following formula:

$R=\log \left(\frac{p_{t}}{p_{t-1}}\right)$

In which, $\mathrm{R}$ is return of $\mathrm{VN}$-Index between two weeks, $p_{t}$ is Wednesday's closing price at week $t, p_{t-1}$ is Wednesday's closing price at week $(t-1)$. The trading volume is also measured on the VN-Index file. Weekly trading volume included in the model is defined as a sum from Thursday's trading volume to the next Wednesday's one.

As regards Singapore stock market, the authors use FTSE ST All-Share Index (FSTAS.SI), which is a modified market-capitalization weighted index comprising of all companies within the top 98 percent by full market capitalization of the SGX Mainboard. FSTAS.SI combined the indices of large-cap, mid-cap and small-cap stocks. Regarding Thailand Stock Market, the paper uses the SET Index, which is a capitalization-weighted index of stocks traded on the Stock Exchange of Thailand.

The measurement of return and trading volume for these aforementioned two markets is similar to that of Vietnam Stock Market and VN-Index.

\subsubsection{Proxy of Investor Overconfidence}

Investor sentiment is chosen as proxy for investor overconfidence. Although investor sentiment is aggregated on the whole market level, which includes both rational investors and overconfident investors. As indicated in the model (Baker \& Stein, 2004), overconfident investors characterized by changes of market variables (high liquidity, high trading volume) should be considered the most significant factor that adds up to investor sentiment. In addition, Odean (1998), Hirshleifer and Luo (2001) also state that optimistic investors tend to be overconfident. Baker and Stein (2004) theoretically show that when shorting is relatively costly, sentimental investors are inclined to become overconfident and trade more actively when they are optimistic.

In general, this relationship can be explained as: An increase in trading volume indicates the participation of overconfident investors in the market, which can be represented by an increase in investor sentiment. The 
investor sentiment measure is called Equity Market Sentiment Index (EMSI), which was developed (Bandopadhyaya \& Jones, 2016). This measure relates the rank of a stock's riskiness to the rank of its return and therefore directly measures the market's pricing of the riskreturn trade-off.

High investor sentiment are associated with how much risk inherent to an equity market investors are willing to accept. As an explanation, overconfident investors raise trading volume due to subjective judgement of information, invest in high-risk stocks due to overestimation of their own skills and knowledge. It once again confirms the fact that investor sentiment can represent investor overconfidence.

Data was collected over the period from January $1^{\text {st }} 2014$ to December $31^{\text {st }} 2018$, daily returns for each of the securities. For each security, the authors also compute the average standard deviation of the daily returns over the previous five days (the "historic volatility") for each day of the sample period. We then rank the daily rate of return and rank the historic volatility and compute the Spearman rank correlation coefficient between the rank of the daily returns for each firm and the rank of the historic volatility of the returns for each firm, and multiply the result by 100 .

The daily EMSI is therefore computed as follows:

$$
\begin{aligned}
& E M S I=\frac{\sum\left(R_{i r}-\overline{R_{r}}\right)\left(R_{i v}-\overline{R_{v}}\right)}{\left[\sum\left(R_{i r}-\overline{R_{r}}\right)^{2} \sum\left(R_{i v}-\overline{R_{v}}\right)^{2}\right]^{\frac{1}{2}}} * 100 ;-100 \leq E M S I \leq \\
& +100
\end{aligned}
$$

where $R_{i r}$ and $R_{i v}$ are the rank of the daily return and the historical volatility for security $i$, respectively, and $\overline{R_{r}}$ and $\overline{R_{v}}$ are the population mean return and historical volatility rankings, respectively. The weekly EMSI is calculated as the average of daily EMSI in one week from Wednesday's closing value to the follow Wednesday's one.

If the market's appetite for risk were fixed, stock price changes would be driven only by unanticipated shifts in economic risk. If the appetite for risk grows and economic risks are unchanged, investors will feel overcompensated for these risk levels and the sense of overcompensation will grow as the level of risk grows. As investors take advantage of what they see as an improving risk-return trade off, stock price will change in line with their risk. Price of high-risk stocks should be higher than low-risk ones and the riskiest currency should rally the most. Thus, a risk appetite index could be constructed based upon the strength of the correlation between the order of stock performance and the order of stock risk.

\subsection{Methodology}

\subsubsection{ADF Test for Stationary Time Series}

Before testing statistical hypotheses, it is necessary to do unit root tests for all time-series variables included in the model. When analyzing any time series, time series data are expected to be stationary in order to ensure its validity because it is a conventional assumption in many time series models. The paper uses Augmented Dickey-Fuller test to check whether the variables is stationary by applying Unit root test.

The regression starts with:

$Y_{t}=\rho Y_{t-1}+u_{t} \quad(-1 \leq \rho \leq 1)$

where $u_{t}$ is a white noise error term. In order to check whether $Y_{t}$ is stationary, $Y_{t}$ is regressed on its lagged value $Y_{t-1}$ and test the hypothesis that $\rho$ is statistically equal to 1 . If it is, then $Y_{t}$ is non-stationary because it means that $Y_{t}$ becomes a random walk model without drift, which is a non-stationary stochastic process.

Subtracting $Y_{t-1}$ from both sides of (3.3):

$$
\begin{aligned}
Y_{t}-Y_{t-1}=\rho Y_{t-1}- & Y_{t-1}+u_{t} \\
& =(\rho-1) Y_{t-1}+u_{t}
\end{aligned}
$$

Which can be written as followed:

$\Delta Y_{t}=\delta Y_{t-1}+u_{t}$

where $\delta=(p-1)$ and $\Delta Y_{t}$ is the first difference of $Y_{t}$

The null hypothesis is $H_{0}: \delta=0$. If the null hypothesis $H_{0}$ or $\delta=0$ could not be rejected, then $\rho=1$, we accept that $Y_{t}$ has a unit root or it is non-stationary.

\subsubsection{Cointegration}

In general, non-stationary time series are said to be cointegrated if there is a stationary linear combination, provided that these time series become stationary at the same level of difference. In order to test cointegration, Johansen test was employed, which is a multivariate generalization of ADF. It is suitable for this model of three variables as it can estimate all cointegrating vectors as there are three variables with unit root, there are no more than two cointegrating vectors. Consider that $\mathrm{Yt}$ is a vector of non-stationary variables which become stationary at the same level of difference. A vector autoregression (VAR) in levels can be presented as followed:

$\Delta x_{t}=\prod x_{t-1}+\sum_{i=1}^{k-1} \prod_{i} \Delta x_{t-i}+u_{t}$

where $\Delta$ is the difference operator, $u_{t}$ is a white noise vector.

\subsubsection{Optimal Lag Order Selection}

The model presents information criteria including Likelihood Ratio Test (LR), Final Prediction Error (FPE), 
Akaike Information Criterion (AIC), Schwarz Information Criterion (SC) and Hannan-Quinn Information Criterion (HQ), which will be compared for selecting the optimal lag order in the model.

\subsubsection{Granger Causality Test}

Odean (1998) and Gervais and Odean (2001) put forward the overconfidence hypothesis, in which they argue that market gains make investors overconfident and trade more aggressively in subsequent periods. In statistical term, there is a positive causal relation running from lagged returns to current volume.

The paper aims to test whether an increase in stock returns $(R)$ is followed by an increase in trading volume $(V)$, and vice versa. In other words, increase in stock return affects trading volume with certain lag order. The Granger causality tests are chosen to examine this hypothesis.

The first Granger causality test is applied as below:

$$
\begin{aligned}
& V_{t}^{w}=\alpha_{1}+\sum_{j=1}^{p} a_{j} V_{t-j}^{w}+\sum_{j=1}^{p} b_{j} R_{t-j}^{w}+\varepsilon_{1 t} \\
& R_{t}^{w}=\alpha_{2}+\sum_{j=1}^{p} c V_{t-j}^{w}+\sum_{j=1}^{p} d_{j} R_{t-j}^{w}+\varepsilon_{2 t}
\end{aligned}
$$

$H_{0}: b_{j}, c_{j}=0$ for all $j$. Market gains (losses) increase (decrease) investors' overconfidence, which make them increase (decrease) their trading volume in subsequent periods.

$H_{1}: b_{j}, c_{j} \neq 0$ for all $j$. Market gains (losses) do not increase (decrease) investors' overconfidence, thus do not make them increase (decrease) their trading volume in subsequent periods.

Where $V$ is the weekly trading volume, $R$ is the weekly stock return. The number of lags $p$ is chosen by using the Akaike information criterion (AIC). If the coefficients $b_{j}, c_{j}$ in equation (3.7) and (3.8) are statistically significant, it is reasonable to include lagged stock return and lagged trading volume in the forecast of future volume

The main purpose of applying the first Granger causality test is to find the causal relationship between stock returns and trading volume. If the null hypothesis is rejected, it indicates that stock returns Granger-cause trading volume. In other words, high (low) stock returns increase (decrease) confidence of investors resulting in aggressive trading activity. The finding of positive causality running from stock returns to trading volume is not adequate to support overconfidence hypothesis if we cannot find evidence that the market gains lead to investor overconfidence. In this research, EMSI is used as a proxy for investor confidence level.

To directly examine whether the causal relationship between lagged stock returns and current trading volume is due to overconfidence, the second Granger causality test is applied as in the following model:

$$
\begin{aligned}
& E M S I_{t}^{w}= \\
& \alpha_{3}+\sum_{j=1}^{p} g_{j} V_{t-j}^{w}+\sum_{j=1}^{p} h_{j} R_{t-j}^{w}+\sum_{j=1}^{p} i_{j} E M S I_{t-j}^{w}+\varepsilon_{2 t}
\end{aligned}
$$

where EMSI is the index of investor confidence level which has been describe in section III.1 - Data description.

The second Granger causality test is to examine the causal relationship between stock returns and EMSI, represented by null hypothesis: $H 0: h_{j}=0$, for all $\mathrm{j}$. If the null hypothesis mentioned above is rejected, then overconfidence hypothesis holds. Specifically, it will provide a clear evidence that market gains make investors become more confident given the confirmation of causality deriving from stock returns to trading volume.

The third Granger causality test is presented below:

$$
\begin{aligned}
& V_{t}^{m}= \\
& \alpha_{1}+\sum_{j=1}^{p} a_{j} V_{t-j}^{m}+\sum_{j=1}^{p} b_{j} R_{t-j}^{m}+\sum_{j=1}^{p} c_{j} E M S I_{t-j}^{m}+\varepsilon_{1 t}
\end{aligned}
$$

$$
\begin{aligned}
& R_{t}^{m}= \\
& \alpha_{2}+\sum_{j=1}^{p} d_{j} V_{t-j}^{m}+\sum_{j=1}^{p} e_{j} R_{t-j}^{m}+\sum_{j=1}^{p} f_{j} E M S I_{t-j}^{m}+\varepsilon_{2 t}
\end{aligned}
$$

The third Granger causality test is to provide forecast values as to whether EMSI contains information to predict stock returns and trading volume. In other words, it may suggest any impact of overconfidence on the performance of market measured by returns and trading volume.

\subsubsection{Vector Autoregressive Model (VAR)}

Vector Autoregressive Model (VAR) is a system of simultaneous equations, in which all variables are endogenous variables. Independent variables is endogenous variables in lag times. Structure of a VAR model includes a number of equations and has lagged values of variables. It is a dynamic model of a few time series. Assume that the $\operatorname{VAR}(p)$ model is stationary, and there are no restrictions on the parameters of the model. In notation, each equation in the $\operatorname{VAR}(\mathrm{p})$ may be written as:

$$
y_{i}=Z \pi_{i}+e_{i}, \quad i=1, \ldots, n
$$

where $y_{i}$ is a $(T \times 1)$ vector of observations on the $i^{\text {th }}$ equation, $Z$ is a $(T \times k)$ matrix with $t^{\text {th }}$ row given by $Z_{t}^{\prime}=\left(1, Y_{t-1}^{\prime}, \ldots, Y_{t-p}^{\prime}\right), k=n p+1, \quad \pi_{i}$ is a $(k \times 1)$ vector of parameters and $e_{i}$ is a $(T \times 1)$ error with covariance matrix $\sigma_{i}^{2} I_{T}$. 


\section{Empirical Results}

\subsection{Overconfidence in Vietnam Stock Market}

\subsubsection{Stationarity Test on Time Series}

Firstly, the Augmented Dickey-Fuller (ADF) test is used to examine whether all the time series variables are stationary (see Table 1).

Table 12: Unit root test for $R_{w} V_{w}$ and $E M S I_{w}$ in Vietnam stock market

\begin{tabular}{|c|c|c|}
\hline $\begin{array}{c}\text { Null Hypothesis: } \mathbf{R}_{\mathbf{w}} \\
\left(\mathbf{V}_{\mathbf{w}}, \text { EMSI }_{\mathbf{w}}\right) \text { has a unit root }\end{array}$ & \\
\hline Exogenous: Constant & & \\
\hline Lag Length: 1 (Fixed) & t-Statistic & Prob.* \\
\hline $\begin{array}{c}\text { Augmented Dickey-Fuller test } \\
\text { statistic }\end{array}$ & -10.9115 & 0.0000 \\
\hline $\mathrm{R}_{\mathrm{w}}$ & -12.0822 & 0.0000 \\
\hline $\mathrm{V}_{\mathrm{w}}$ & -11.6854 & 0.0000 \\
\hline EMSI $_{\mathrm{w}}$ &
\end{tabular}

Because the Augmented Dickey-Fuller test statistic is higher than critical values at all significance level of $1 \%, 5 \%$ and $10 \%$ in absolute term, the null hypothesis has been rejected at $1 \%$ significance level. It means that all variables which are later included in the VAR model and Granger Causality test are stationary.

\subsubsection{Lag Order Selection}

To determine the number of lags to be included in the VAR model, a set of lag order criteria are used, including: Sequential Modified Likelihood - Ratio test (LR), Final Prediction Error (FPE), Akaike Information Criterion (AIC), Schwarz Information Criterion (SC) and Hannan-Quinn Information Criterion (HQ). If there is any disagreement between these criteria, the lag order will be selected based on the Akaike Information Criterion (AIC). As can be seen from the Table 2, all information criteria choose one lag as the optimal lag order to be included in VAR model. It is expected that there is a causal relation between return with the lag of one week and current volume as well as current investor overconfidence

Table 13: Lag order selection in Vietnam stock market

\begin{tabular}{|c|c|c|c|c|c|c|}
\hline \multicolumn{4}{|c|}{ Endogenous variables: $\mathrm{EMSI}_{\mathrm{W}} \mathrm{R}_{\mathrm{W}} \mathrm{V}_{\mathrm{W}}$} & & & \\
\hline \multicolumn{3}{|c|}{ Exogenous variables: $\mathrm{C}$} & & & & \\
\hline \multicolumn{4}{|c|}{ Included observations: 239} & & & \\
\hline Lag & $\log L$ & $\mathbf{L R}$ & FPE & AIC & SC & HQ \\
\hline 0 & -969.9552 & NA & 0.689529 & 8.141884 & 8.185522 & 8.159469 \\
\hline 1 & -932.0493 & $74.54288 *$ & $0.541383 *$ & 7.899994* & $8.074545^{*}$ & $7.970333^{*}$ \\
\hline 2 & -925.2225 & 13.25368 & 0.551342 & 7.918180 & 8.223643 & 8.041273 \\
\hline 3 & -920.5713 & 8.913202 & 0.571830 & 7.954572 & 8.390948 & 8.130419 \\
\hline & & indicates las & ected by the & & & \\
\hline
\end{tabular}

\subsubsection{Granger Causality Test}

The bivariate Granger causality test is performed with stock return, trading volume and Equity Market Sentiment Index - EMSI which is the proxy for confidence level of investors. The Table 3 demonstrates the test for causal relationship between these three variables.

Firstly, the null hypothesis that weekly stock returns do not Granger-cause weekly trading volume cannot be rejected at significant level of $5 \%$ as indicated by the $\mathrm{p}$ value. Therefore, it is not possible to conclude that investors aggressively trade after making a profit with the lag order of one week. It is thus in disagreement with previous findings of (Odean, 1998) and (Gervais \& Odean, 2001) about overconfidence hypothesis. The null hypothesis that trading volume Granger-cause stock returns cannot be rejected, either.
Secondly, the causal relationship between stock return and Equity Market Sentiment Index (EMSI) are tested. According to the results in the Table 3, the null hypothesis that stock returns Granger-cause EMSI is rejected at significant level of $1 \%$. It indicates that investor confidence can be driven by stock returns. It is likely that the more profitable the investment gets, the more confidence the investors have as they have more trust in their competency and the accuracy of information they hold. The exact sign of this relationship should be examined through the VAR model in the next section.

Thirdly, the causal relationship running from overconfidence proxy to market variables are not completely apparent. While the hypothesis that EMSI Granger-cause trading volume is rejected at significant level of $1 \%$, the null hypothesis that EMSI does not 
Granger-cause stock returns is accepted. This result suggests that overconfidence among Vietnamese investors affects the market volume but does not affect the market return at one lag period. It may indicate that Vietnam stock market is not completely efficient as investor overconfidence do drive the market to certain extent.

Table 14: Granger Causality Tests with lag 1

\begin{tabular}{|c|c|c|c|}
\hline Null Hypothesis: & Obs & F-Statistic & Prob. \\
\hline $\mathrm{R}_{\mathrm{W}}$ does not Granger Cause $\mathrm{EMSI}_{\mathrm{W}}$ & 246 & 9.37360 & 0.0024 \\
\hline \multicolumn{2}{|l|}{ EMSI $_{\mathrm{W}}$ does not Granger Cause $\mathrm{R}_{\mathrm{W}}$} & 0.31478 & 0.5753 \\
\hline $\mathrm{V}_{\mathrm{W}}$ does not Granger Cause $\mathrm{EMSI}_{\mathrm{W}}$ & 246 & 38.7769 & 2.E-09 \\
\hline \multicolumn{2}{|l|}{ EMSI $_{\mathrm{W}}$ does not Granger Cause $V_{W}$} & 49.8150 & 2.E-11 \\
\hline $\mathrm{V}_{\mathrm{W}}$ does not Granger Cause $\mathrm{R}_{\mathrm{W}}$ & 246 & 0.25903 & 0.6112 \\
\hline \multicolumn{2}{|l|}{$\mathrm{R}_{\mathrm{W}}$ does not Granger Cause $\mathrm{V}_{\mathrm{W}}$} & 1.05095 & 0.3063 \\
\hline
\end{tabular}

\subsubsection{The Vector Autoregressive Model (VAR)}

As the Granger causality test suggests a causality link between variables, the VAR model depicts how variables correlate with each other at the optimal lag period.

Table 15: VAR model in Vietnam stock market

\begin{tabular}{|c|c|c|c|}
\hline \multicolumn{4}{|c|}{ Equation: $\operatorname{EMSI}_{\mathrm{W}}=\mathbf{C}(1) * \operatorname{EMSI}_{\mathrm{w}}(-1)+\mathrm{C}(2) * \mathbf{R}_{\mathrm{w}}(-1)+\mathrm{C}(3) * \mathrm{~V}_{\mathrm{w}}(-1)+\mathbf{C}(4)$} \\
\hline \multicolumn{3}{|c|}{ Observations: 246} & \\
\hline R-squared & 0.183503 & Mean dependent var & -0.717246 \\
\hline $\begin{array}{l}\text { Adjusted R- } \\
\text { squared }\end{array}$ & 0.173381 & S.D. dependent var & 6.365784 \\
\hline $\begin{array}{l}\text { S.E. of } \\
\text { regression }\end{array}$ & 5.787681 & Sum squared resid & 8106.334 \\
\hline $\begin{array}{c}\text { Durbin-Watson } \\
\text { stat }\end{array}$ & 1.951494 & & \\
\hline \multicolumn{4}{|c|}{ Equation: $\mathbf{R}_{\mathrm{W}}=\mathbf{C}(5) * \operatorname{EMSI}_{\mathrm{W}}(-1)+\mathbf{C}(6) * \mathbf{R}_{\mathrm{W}}(-1)+\mathbf{C}(7) * \mathbf{V}_{\mathrm{W}}(-1)+\mathbf{C}(8)$} \\
\hline \multicolumn{3}{|c|}{\begin{tabular}{|l|l|} 
Observations: 246 & \\
\end{tabular}} & \\
\hline R-squared & 0.002523 & Mean dependent var & -0.000874 \\
\hline $\begin{array}{l}\text { Adjusted R- } \\
\text { squared }\end{array}$ & -0.009843 & S.D. dependent var & 0.010849 \\
\hline $\begin{array}{l}\text { S.E. of } \\
\text { regression }\end{array}$ & 0.010902 & Sum squared resid & 0.028765 \\
\hline $\begin{array}{l}\text { Durbin-Watson } \\
\text { stat }\end{array}$ & 2.007282 & & \\
\hline \multicolumn{4}{|c|}{ Equation: $V_{W}=C(9) * \operatorname{EMSI}_{w}(-1)+C(10) * R_{W}(-1)+C(11) * V_{w}(-1)+C(12)$} \\
\hline \multicolumn{3}{|c|}{ Observations: 246} & \\
\hline R-squared & 0.190935 & Mean dependent var & -3.601367 \\
\hline $\begin{array}{l}\text { Adjusted R- } \\
\text { squared }\end{array}$ & 0.180906 & S.D. dependent var & 34.18077 \\
\hline $\begin{array}{l}\text { S.E. of } \\
\text { regression }\end{array}$ & 30.93491 & Sum squared resid & 231586.4 \\
\hline $\begin{array}{c}\text { Durbin-Watson } \\
\text { stat }\end{array}$ & 1.917192 & & \\
\hline
\end{tabular}

The sign of the correlation coefficient indicates the direction in which these variables move. There are important points worth noting from the Table 4 .

- The correlated coefficient between V_w and R_w (-1) is positive at $1 \%$ significant level, which shows the positive relationship between stock return and trading volume in Vietnam stock market. Although the causal relation between V_W and R_w (-1) is not proved in Granger causality test, $\mathrm{V}_{-} \mathrm{W}$ and $\overline{\mathrm{R}}_{-} \mathrm{W}(-1)$ were found to move in the same direction, which is in agreement with previous studies.

- The coefficient between R_w (-1) and EMSI_w is positive, suggesting a positive relationship between investor confidence and one-lag stock return in Vietnam stock market at the significant level of $1 \%$.

EMSI_W (-1) is positively correlated to V_w, which means that higher confidence level results in a higher trading volume with one lag period.

\subsection{Testing Overconfidence in Singapore Stock Market}

\subsubsection{Stationarity Test on Time Series}

Applying similar process, the paper also use ADF test to examine whether all the time series variables of Singapore stock market are stationary. Because Augmented DickeyFuller test statistic is higher than critical values at all significance level of $1 \%, 5 \%$ and $10 \%$ in absolute term at $1 \%$ significance level, the null hypothesis is rejected. It means that all variables including stock returns, trading volume and EMSI are stationary (see Table 5).

Table 16: Unit root test for $R_{w} V_{w}$ and $E M S I_{w}$ in Singapore stock market

\begin{tabular}{|c|c|c|}
\hline $\begin{array}{c}\text { Null Hypothesis: } \mathbf{R}_{\mathbf{w}}\left(\mathbf{V}_{\mathbf{w}}, \mathbf{E M S I}_{\mathrm{w}}\right) \text { has a } \\
\text { unit root }\end{array}$ & & \\
\hline Exogenous: Constant & & \\
\hline Lag Length: 1 (Fixed) & & \\
\hline Augmented Dickey-Fuller test statistic & t-Statistic & Prob. \\
\hline $\mathrm{R}_{\mathrm{w}}$ & -8.813629 & 0.0000 \\
\hline $\mathrm{V}_{\mathrm{w}}$ & -5.276685 & 0.0000 \\
\hline EMSI $_{\mathrm{w}}$ & -10.03850 & 0.0000 \\
\hline
\end{tabular}

\subsubsection{Lag Order Selection}

As can be seen from Table 6, the lag of one period is suggested by all information criteria. The principle of information criteria is to choose the lag order at which the value calculated by each criterion is minimum in order to ensure the stability of the model. Therefore, the lag of one period is chosen for testing hypothesis of overconfidence. 
Table 17: Lag order selection in Singapore stock market

\begin{tabular}{|c|c|c|c|c|c|c|}
\hline \multicolumn{4}{|c|}{ Endogenous variables: EMSI $_{W} R_{W} V_{W}$} & & & \\
\hline \multicolumn{3}{|c|}{ Exogenous variables: $\mathrm{C}$} & & \multirow[b]{3}{*}{ AIC } & \multirow[b]{3}{*}{ SC } & \multirow[b]{3}{*}{ HQ } \\
\hline \multicolumn{4}{|c|}{ Included observations: 166} & & & \\
\hline Lag & $\log L$ & LR & FPE & & & \\
\hline 0 & -3362.603 & NA & $8.18 \mathrm{e}+13$ & 40.54943 & 40.60567 & 40.57226 \\
\hline 1 & -3318.472 & $86.13503^{*}$ & $5.36 \mathrm{e}+13^{*}$ & $40.12617 *$ & $40.35113^{*}$ & $40.21748^{*}$ \\
\hline 2 & -3314.160 & 8.258959 & $5.67 \mathrm{e}+13$ & 40.18266 & 40.57634 & 40.34246 \\
\hline & & dicates lag o & ed by the cri & & & \\
\hline
\end{tabular}

\subsubsection{Granger Causality Test}

Results of the bivariate Granger causality test at 1 week lag is presented in Table 7:

Firstly, the null hypothesis that weekly stock returns do not Granger-cause weekly trading volume is rejected at $5 \%$ significant level. Similar to Vietnamese investors, Singaporean investors eagerly raise their volume of transactions after seeing increase in returns. In the meantime, the null hypothesis that trading volume Grangercause stock returns is also rejected at $1 \%$ significant level, suggesting potential negative impact of excessive trading volume on stock returns which should be further investigated in VAR model.

Next, the causal relationship between stock return and Equity Market Sentiment Index (EMSI) is tested. Specifically, the null hypothesis that stock returns Grangercause EMSI is rejected at significant level of $1 \%$. It implies that increase in stock returns can contribute to investor overconfidence: If investors yield more returns, they become more confident thus irrationally increase their trading volume. Regarding impact of overconfidence on market variables, there is a causal relation running from EMSI_w (-1) to V_w because the null hypothesis that EMSI_w (-1) does not Granger-cause V_w is rejected at 5\% confidence level.

Table 18: Granger causality tests in Singapore with lag 1

\begin{tabular}{|c|c|c|c|}
\hline Null Hypothesis: & Obs & F-Statistic & Prob. \\
\hline $\begin{array}{c}\mathrm{R}_{\mathrm{W}} \text { does not Granger Cause } \\
\text { EMSI }_{\mathrm{W}}\end{array}$ & 173 & 19.0541 & 2.E-05 \\
\hline \multicolumn{2}{|c|}{ EMSI $_{\mathrm{W}}$ does not Granger Cause $\mathrm{R}_{\mathrm{W}}$} & 0.17653 & 0.6749 \\
\hline $\begin{array}{c}\mathrm{V}_{\mathrm{W}} \text { does not Granger Cause } \\
\text { EMSI }_{\mathrm{W}}\end{array}$ & 173 & 0.42648 & 0.5146 \\
\hline \multicolumn{2}{|c|}{ EMSI $_{W}$ does not Granger Cause $V_{W}$} & 6.47553 & 0.0118 \\
\hline $\mathrm{V}_{\mathrm{W}}$ does not Granger Cause $\mathrm{R}_{\mathrm{W}}$ & 173 & 8.81665 & 0.0034 \\
\hline \multicolumn{2}{|c|}{$\mathrm{R}_{\mathrm{W}}$ does not Granger Cause $\mathrm{V}_{\mathrm{W}}$} & 3.96176 & 0.0481 \\
\hline
\end{tabular}

\subsubsection{The Vector Autoregressive Model (VAR)}

To analyse the trend of the mutual impact among three variables, the authors estimate the coefficients of OLS regression on VAR model. In terms of stock returns and trading volume, it is essential to look into the relation between trading volume and lagged stock returns, and the relation between stock returns and lagged trading volume. In the former test, there is a positive relationship between these variables at 5\% significant level, which means that one-lag stock returns are positively correlated with trading volume. Whereas, in the latter test, a negative relation between lagged trading volume and stock returns is found, which means that excessive trading volume will harm the subsequent returns.

Table 19: VAR model in Singapore stock market

\begin{tabular}{|c|c|c|c|}
\hline \multicolumn{4}{|c|}{ Equation: EMSI $_{W}=\mathbf{C}(1) * \operatorname{EMSI}_{W}(-1)+C(2) * \mathbf{R}_{W}(-1)+C(3) * V_{W}(-1)+C(4)$} \\
\hline \multicolumn{3}{|c|}{ Observations: 173} & \\
\hline R-squared & 0.107488 & Mean dependent var & -2.324152 \\
\hline Adjusted R-squared & 0.091644 & S.D. dependent var & 5.434722 \\
\hline S.E. of regression & 5.179709 & Sum squared resid & 4534.167 \\
\hline Durbin-Watson stat & 1.923283 & & \\
\hline \multicolumn{4}{|c|}{ Equation: $\mathbf{R}_{\mathrm{W}}=\mathbf{C}(\mathbf{5}) * \operatorname{EMSI}_{\mathrm{W}}(-1)+\mathbf{C}(6) * \mathbf{R}_{\mathrm{W}}(-1)+\mathbf{C}(7) * \mathrm{~V}_{\mathrm{W}}(-1)+\mathbf{C}(\mathbf{8})$} \\
\hline \multicolumn{3}{|c|}{ Observations: 173} & \\
\hline R-squared & 0.065039 & Mean dependent var & -0.000170 \\
\hline Adjusted R-squared & 0.048442 & S.D. dependent var & 0.006443 \\
\hline S.E. of regression & 0.006285 & Sum squared resid & 0.006677 \\
\hline Durbin-Watson stat & 2.062718 & & \\
\hline \multicolumn{4}{|c|}{ Equation: $V_{W}=C(9) * \operatorname{EMSI}_{W}(-1)+C(10) * R_{W}(-1)+C(11) * V_{W}(-1)+C(12)$} \\
\hline \multicolumn{3}{|c|}{ Observations: 173} & \\
\hline R-squared & 0.307808 & Mean dependent var & $1.15 \mathrm{E}+09$ \\
\hline Adjusted R-squared & 0.295521 & S.D. dependent var & $2.73 \mathrm{E}+08$ \\
\hline S.E. of regression & $2.29 \mathrm{E}+08$ & Sum squared resid & $8.90 \mathrm{E}+18$ \\
\hline Durbin-Watson stat & 2.174367 & & \\
\hline
\end{tabular}

For the relation between overconfidence and market variables (return, volume), the VAR model shows that 
EMSI is positively related to lagged stock return at $1 \%$ significant level. Lagged values of EMSI is positively related to trading volume, indicating that as EMSI at the lag of one week increases, the current trading volume also increases. Combined all the results from VAR model, the Singapore stock market also suffer from overconfidence bias. Specifically, stock returns have an impact on subsequent confidence level of investors, making them to trade more aggressively. However, it will eventually lower the stock returns (see Table 8).

\subsection{Testing Overconfidence in Thailand Stock Market}

\subsubsection{Stationarity Test on Time Series}

The results suggest that all variables including stock returns, trading volume and EMSI are stationary (see Table 9). Because Augmented Dickey-Fuller test statistic is higher than critical values at all significance level of $1 \%, 5 \%$ and $10 \%$ in absolute term at $5 \%$ significance level, the null hypothesis is rejected.

Table 20: Unit root test for $R_{w} V_{w}$ and $E M S I_{w}$ in Thailand

\begin{tabular}{|c|c|c|}
\hline $\begin{array}{c}\text { Null Hypothesis: } \mathbf{R}_{\mathrm{w}}\left(\mathbf{V}_{\mathrm{w}}, \mathbf{E M S I}_{\mathrm{w}}\right) \text { has a } \\
\text { unit root }\end{array}$ & & \\
\hline Exogenous: Constant & & \\
\hline Lag Length: 1 (Fixed) & & \\
\hline Augmented Dickey-Fuller test statistic & t-Statistic & Prob. $^{*}$ \\
\hline $\mathrm{R}_{\mathrm{w}}$ & -6.309635 & 0.0000 \\
\hline $\mathrm{V}_{\mathrm{w}}$ & -2.980843 & 0.0381 \\
\hline EMSI $_{\mathrm{w}}$ & -6.312522 & 0.0000 \\
\hline
\end{tabular}

\subsubsection{Lag Order Selection}

As for Thailand stock market, there is inconsistency among information criteria in the selection of optimal lag. The Information Criterion (AIC) is prioritized. The smallest value calculated by AIC is witnessed at the lag of 4 periods. Therefore, the lag of 1 period is chosen for testing hypothesis of overconfidence (see Table 10).

Table 21: Lag order selection in Thailand stock market

\begin{tabular}{|c|c|c|c|c|c|c|}
\hline \multicolumn{4}{|c|}{ Endogenous variables: EMSI $_{W} R_{W} V_{W}$} & & & \\
\hline \multicolumn{3}{|c|}{ Exogenous variables: $\mathrm{C}$} & & \multirow[b]{3}{*}{ AIC } & \multirow[b]{3}{*}{ SC } & \multirow[b]{3}{*}{ HQ } \\
\hline \multicolumn{4}{|c|}{ Included observations: 239} & & & \\
\hline Lag & $\log L$ & LR & FPE & & & \\
\hline 0 & -943.3066 & NA & 0.551702 & 7.918884 & 7.962522 & 7.936469 \\
\hline 1 & -880.8874 & 122.7492 & 0.352833 & 7.471861 & $7.646411 *$ & $7.542200^{*}$ \\
\hline 2 & -869.6749 & 21.76819 & 0.346374 & 7.453346 & 7.758809 & 7.576439 \\
\hline 3 & -861.9511 & 14.80127 & 0.350127 & 7.464026 & 7.900402 & 7.639873 \\
\hline 4 & -847.0913 & $28.10299^{*}$ & $0.333431 *$ & $7.414990 *$ & 7.982279 & 7.643592 \\
\hline 5 & -843.0359 & 7.567865 & 0.347614 & 7.456367 & 8.154569 & 7.737723 \\
\hline & & licates lag or & ed by the crit & & & \\
\hline
\end{tabular}

\subsubsection{Granger Causality Test}

It is noted that in Thailand stock market, the null hypothesis that stock returns Granger-cause trading volume cannot be rejected, which means that there is no causal relationship running from stock returns to market volume.

Table 11: Granger causality tests in Thailand with lag 4

\begin{tabular}{|c|c|c|c|}
\hline Null Hypothesis: & Obs & F-Statistic & Prob. \\
\hline $\begin{array}{c}\mathrm{R}_{\mathrm{W}} \text { does not Granger Cause } \\
\text { EMSI }\end{array}$ & 243 & 2.10154 & 0.0814 \\
\hline \multicolumn{2}{|c|}{ EMSI $_{\mathrm{W}}$ does not Granger Cause $\mathrm{R}_{\mathrm{W}}$} & 1.54090 & 0.1911 \\
\hline \multicolumn{2}{|c|}{$\mathrm{V}_{\mathrm{W}}$ does not Granger Cause } \\
$\begin{array}{c}\text { EMSI } \\
\text { EMS }\end{array}$ & 243 & 1.15027 & 0.3336 \\
\hline \multicolumn{2}{|c|}{ EMSI $_{\mathrm{W}}$ does not Granger Cause $\mathrm{V}_{\mathrm{W}}$} & 1.54949 & 0.1887 \\
\hline $\mathrm{V}_{\mathrm{W}}$ does not Granger Cause $\mathrm{R}_{\mathrm{W}}$ & 243 & 1.69575 & 0.1517 \\
\hline \multicolumn{2}{|c|}{$\mathrm{R}_{\mathrm{W}}$ does not Granger Cause $\mathrm{V}_{\mathrm{W}}$} & 0.64396 & 0.6317 \\
\hline
\end{tabular}

Whereas, the null hypothesis that weekly stock returns do not Granger-cause weekly EMSI can be rejected at $10 \%$ significant level. Similar to other two markets, the causal relationship running from stock returns to investor overconfidence level also exists. However, the impact of EMSI on market returns and trading volume cannot be proved through Granger causality test. It may imply that overconfidence bias does not drive the Thailand stock market (see Table 11).

\subsubsection{The Vector Autoregressive Model (VAR)}

As can be seen from the VAR model, coefficient between lagged stock returns and EMSI is positive at significant level of $5 \% \quad(\beta=116.6846)$, while one-lag EMSI has a positive impact on subsequent return at $5 \%$ significant level 
( $\beta=0.000236$ ), which is contrast to all findings that found existence of overconfidence. However, there is no evidence of meaningful relationship between EMSI and volatility. In addition, another finding worth mentioning is that lagged volume increases market returns as the correlation coefficient between $\mathrm{R} \_\mathrm{w}$ and $\mathrm{V} \_\mathrm{w}(-4)$ is positive at significance level $5 \%(\beta=7.38 \mathrm{E}-0)$.

To sum up, there is positive relationship between confidence level of Thai investors and stock returns. Yet becoming more confident proves to be beneficial to Thailand investors as EMSI is positively correlated with market returns with the lag of one week. Similarly, the trading volume is also positively correlated with market returns with the lag of four weeks. These results may indirectly imply that Thailand investors are under-confident, which means that by raising their confidence and trading more actively, Thailand investors are likely to yield more profits (see Table 12).

Table 22: VAR model in Thailand stock market

\begin{tabular}{|c|c|c|c|}
\hline \multicolumn{4}{|c|}{ 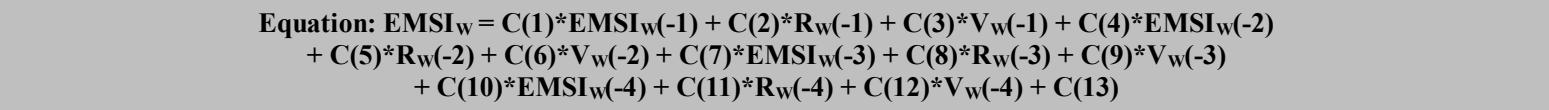 } \\
\hline \multicolumn{4}{|c|}{ Observations: 243} \\
\hline R-squared & 0.061536 & Mean dependent var & -0.802451 \\
\hline Adjusted R-squared & 0.012572 & S.D. dependent var & 5.479973 \\
\hline S.E. of regression & 5.445416 & Sum squared resid & 6820.089 \\
\hline Durbin-Watson stat & 1.936787 & & \\
\hline \multicolumn{4}{|c|}{ 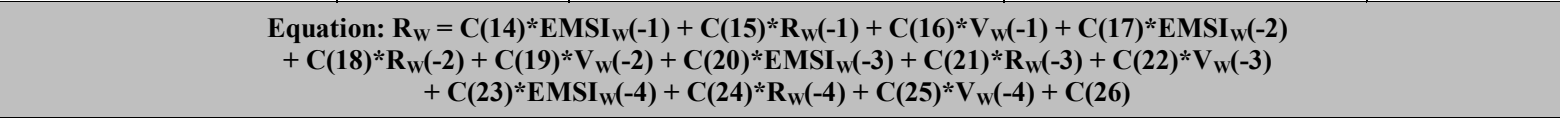 } \\
\hline \multicolumn{4}{|c|}{ Observations: 243} \\
\hline R-squared & 0.057810 & Mean dependent var & -0.000302 \\
\hline Adjusted R-squared & 0.008653 & S.D. dependent var & 0.007687 \\
\hline S.E. of regression & 0.007654 & Sum squared resid & 0.013475 \\
\hline Durbin-Watson stat & 1.943974 & & \\
\hline \multicolumn{4}{|c|}{ 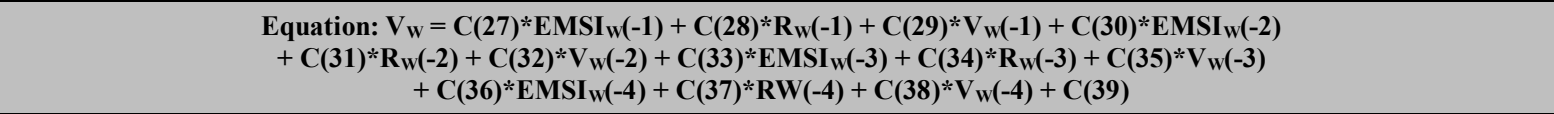 } \\
\hline \multicolumn{4}{|c|}{ Observations: 243} \\
\hline R-squared & 0.501296 & Mean dependent var & 55.08008 \\
\hline Adjusted R-squared & 0.475276 & S.D. dependent var & 18.48436 \\
\hline S.E. of regression & 13.38967 & Sum squared resid & 41235.13 \\
\hline Durbin-Watson stat & 2.016093 & & \\
\hline
\end{tabular}

\section{Discussions}

The similarity in these three markets is that rising stock returns contribute to an increase in investor confidence. In other words, there is evidence that Vietnamese, Singaporean and Thailand investors become more confident when they yield increasing profit in the markets. However, only Vietnam and Singapore stock markets witness a meaningful relation between lagged stock returns and trading volume. It means that there is adequate and concrete evidence of overconfidence in Vietnam and Singapore markets. When weighing up the strength of overconfidence between these two markets, the impact of overconfidence is much stronger in Singapore stock market compared to that of Vietnam (because the correlation coefficients in the $2^{\text {nd }}$ and $3^{\text {rd }}$ hypothesis are much higher in Singapore than in Vietnam). As a result, overconfidence of Vietnamese and Singaporean investors may be attributed to different roots.

In terms of Vietnamese investors, the overconfidence bias can be due to the fact that the market is not efficient enough. To be more specific, there is still high level of insider trading, the process in which companies declare information is not clear and timely enough as well as overoptimistic and misleading information generated by the media. It may encourage investor overestimation of personal information and personal judgement. As a result, 
Vietnamese investors are likely to become overconfident.

For Singaporean investors, as this country has transformed into a global financial hub, its financial success and high financial stability may lead to unrealistic expectations, overoptimistic beliefs and a lack of clear investment planning. As a stark example, questionnaires researched by Singapore Business Review have shown consistent evidence of investor overconfidence during 2015 and 2016. In 2015, they found that $75 \%$ local investors believed they make a gain in 2015 , yet $61 \%$ do not have financial plan and $57 \%$ do not have clear financial goals. In 2016, an average Singaporean investor anticipated at least $9,2 \%$ return in a year while on average, the stock market only yields $3,8 \%$.

On the other hand, regarding Thailand stock market, the causal relation running from stock returns to trading volume cannot be proved. As one of the first two hypotheses (Hypothesis 1, Hypothesis 2) are not accepted, the evidence of overconfidence in Thailand stock market is not solid and its existence is relatively weak. Nevertheless, the VAR model has suggested an interesting idea for Thailand stock market. That is, both high level of confidence and an increase in lagged trading volume have a positive impact on current stock returns. It may suggest that investors in Thailand are under-confident, which infers that a rise in confidence level may help investors yield higher performance in the market. The similar conclusion has been suggested by (Budsaratragoon et al., 2012), in which they found that Thai Government Pension Fund members are risk-adverse and underreact to market movements. As an explanation for this finding, the instability in terms of economic, politic and social system of Thailand makes investors more cautious and undermines their confidence. Since 2004, Thailand has suffered from political turmoil and natural disasters: a devastating tsunami, two military coups, violent street protest, damaging floods and bombing events are among the most significant ones to mention. These events have cause disruption in the operation of Thailand economy, raising doubts in risky investments including stock market.

\section{Conclusions}

In the context that psychological biases are prevalent in all fields of work, especially when it comes to financial decision making. The fact that all individual investors understand their own way of thinking and feeling is very important not only for their own investment performance but also the stability and efficiency of the market as a whole. The competent authorities can also consider the confidence level of investors and investor sentiment as an important indicator when they monitor the stock market when formulate new economic policies. In this research, the results have also suggested some possible measures for investors to overcome the psychological bias and avoid any serious impact on their performance due to consistent mistakes in their decision making. The authors also exhibit solutions for the competent authorities to better market efficiency, creating a stable and well-developed stock market for targeting at being included in the FTSE emerging market portfolio by March 2020.

The paper also presents most outstanding researches up until now about overconfidence bias mainly in the field of finance in a comprehensive and detailed way. Although it has been studied for a long period of time globally but it has not yet been applied much in Vietnam. It will change in the future when more and more financial products are introduced. Being clear about the signs of overconfidence, its causes and impacts, investors are unlikely to follow their emotions and take excessive risks when investing in new financial instruments.

Overall, the paper has found the existence, the strength and also the impacts of overconfidence in three stock markets. The results of the three markets are diversifying. Both Vietnam and Singapore illustrate concrete evidence of overconfidence, in which Singaporean investors show higher degree of overconfidence than Vietnamese investors. These results agree with previous studies about overconfidence in Vietnam and Singapore. As for Thailand stock market, overconfidence is not as clear as the other two markets, yet a direct causal link from increased returns to increased investor confidence was found. From the model, it is strongly believed that Thailand investors are under-confident. The previous findings about Thailand, however, are not consistent. The conclusions drawn from the paper thus continue to add the author's viewpoint to the diverse opinions about this market.

Although the paper has applied successfully approaches developed by previous researchers, the empirical method of study still has limitation. The empirical studies are based on analysis of public historical data. They have high level of confidence yet is hard to control the conditions as there are a lot of factors affecting one event on the market. Hopefully that in the future, the authors could apply the experimental approach to the study of overconfidence in order to control the conditions of the experiments and find more impacts of it on individual level.

\section{References}

Baker, M., \& Stein, J. C. (2004). Market liquidity as a sentiment indicator. Journal of Financial Markets, 7(3), 271-299. doi:10.1016/j.finmar.2003.11.005

Bandopadhyaya, A., \& Jones, A. L. (2016). Measuring Investor Sentiment in Equity Markets. In S. Satchell (eds), Asset 
Management (pp. 258-269). London, England: Palgrave Macmillan. https://doi.org/10.1007/978-3-319-30794-7_11

Barber, B. M., \& Odean, T. (2001). Boys will be Boys: Gender, Overconfidence, and Common Stock Investment. The Quarterly Journal of Economics, 116(1), 261-292. doi: $10.1162 / 003355301556400$

Benos, A. V. (1998). Aggressiveness and survival of overconfident traders. Journal of Financial Markets, 1(3-4), 353-383. doi:10.1016/s1386-4181(97)00010-4

Biais, B., Hilton, D., Mazurier, K., \& Pouget, S. (2005). Judgemental Overconfidence, Self-Monitoring, and Trading Performance in an Experimental Financial Market. Review of Economic Studies, 72(2), 287-312. doi:10.1111/j.1467937x.2005.00333.x

Bong, A., \& Premaratne, G. (2019). The Impact of Financial Integration on Economic Growth in Southeast Asia. Journal of Asian Finance, Economics and Business, 6(1), 107-119. http://doi.org/10.13106/jafeb.2019.vol6.no1.107

Budsaratragoon, P., Lhaopadchan, S., Clacher, I., Hillier, D., \& Hodgson, A. (2012). Allowing flexible personal savings and investment choices in public sector pension plans Implications from an emerging economy. Accounting, Accountability \& Performance, 17(1/2), 1-21.

Chuang, W. I., Lee, B. S., \& Wang, K. L. (2013). US and Domestic Market Gains and Asian Investors' Overconfident Trading Behavior. Financial Management, 43(1), 113-148. doi:10.1111/fima.12030

Dang, H. N., \& Tran, D. M. (2019). Relationship between Accrual Anomaly and Stock Return: The Case of Vietnam. Journal of Asian Finance, Economics and Business, 6(4), 19-26. https://doi.org/10.13106/jafeb.2019.vol6.no4.19

De Bondt, W. F. M. (1998). A portrait of the individual investor. European Economic Review, 42(3-5), 831-844. doi:10.1016/s0014-2921(98)00009-9

De Long, J. B., Shleifer, A., Summers, L., \& Waldmann, R. (1991). The Survival of Noise Traders in Financial Markets. The Journal of Business, 64(1), 1-19. doi:10.3386/w2715

Gervais, S., \& Odean, T. (2001). Learning to Be Overconfident. Review of Financial Studies, 14(1), 1-27. doi:10.1093/rfs/14.1.1

Glaser, M., \& Weber, M. (2007). Overconfidence and trading volume. The Geneva Risk and Insurance Review, 32(1), 1-36. doi:10.1007/s10713-007-0003-3

Helen, X. H. B., \& Lib, S. (2019). Investor overconfidence and trading activity in the Asia Pacific REIT markets. Quarterly Journal of Economics, 116, 261-292.

Hirshleifer, D., \& Luo, G. Y. (2001). On the survival of overconfident traders in a competitive securities market. Journal of Financial Markets, 4(1), 73-84. doi:10.1016/s13864181(00)00014-8
Hur, J., \& Park, C. (2012). Do free trade agreements increase economic growth of the member countries? World development, 40(7), 1283-1294.

Kyle, A. S., \& Wang, F. A. (1997). Speculation Duopoly with Agreement to Disagree: Can Overconfidence Survive the Market Test? The Journal of Finance, 52(5), 2073-2090. doi:10.1111/j.1540-6261.1997.tb02751.x

Lee, J. W., \& Zhao, T. F. (2014). Dynamic relationship between stock prices and exchange rates: Evidence from Chinese stock markets. Journal of Asian Finance, Economics and Business, 1(1), 5-14. https://doi.org/10.13106/jafeb.2014.vol1.no1.5.

My, P. N. N. X., Toan, H. L. D., \& Cuong, N. T. K. (2016). Empirical evaluation of overconfidence hypothesis among investors the evidence in Vietnam stock market. Foreign Trade, 4(46), 1-26.

Odean, T. (1998). Are Investors Reluctant to Realize Their Losses? The Journal of Finance, 53(5), 1775-1798. doi:10.1111/00221082.00072

Phan, D. T. T., Nguyen, T. T. H., \& Bui, T. A. (2019). Going beyond Border? Intention to Use International Bank Cards in Vietnam. Journal of Asian Finance, Economics and Business, 6(3), 315-325. https://doi.org/10.13106/jafeb.2019.vol6.no3.315

Phan Tran Trung, D., \& Pham Quang, H. (2019). Adaptive Market Hypothesis: Evidence from the Vietnamese Stock Market. Journal of Risk and Financial Management, 12(2), 81-96. doi:10.3390/jrfm12020081

Scheinkman, José A., \& Xiong, W. (2003). Overconfidence and Speculative Bubbles. Journal of Political Economy, 111(6), 1183-1220. doi:10.1086/378531

Tai, S., \& Lee, J. W. (2009). Strategies of regional economic integration and WTO accession in Central Asia. Eurasian Journal of Business and Economics, 2(3), 1-14.

Ton, H. T. H., \& Dao, T. K. (2014). The Effects of Psychology on Individual Investors' Behaviors: Evidence from the Vietnam Stock Exchange. Journal of Management and Sustainability, 4(3), 125-134. doi:10.5539/jms.v4n3p125

Trehan, B., \& Sinha, A. K. (2011). A study of existence of overconfidence biases among investors and its impact on investment decision. Asia Pacific Journal, 11, 1-15.

Valadkhani, A., \& Chancharat, S. (2008). Dynamic linkages between Thai and international stock markets. Journal of Economic Studies, 35(5), 425-441.

Wang, F. A. (1998). Strategic trading, asymmetric information and heterogeneous prior beliefs. Journal of Financial Markets, 1(3-4), 321-352.

Wong, J., \& Chan, S. (2003). China-ASEAN free trade agreement: shaping future economic relations. Asian Survey, 43(3), 507526. 